\title{
Exploitation of tidal power in the Bay of Cadiz: ancient tidal mills*
}

\author{
JOSÉ J. ALONSO DEL ROSARIO ${ }^{1}$, JUAN M. VIDAL PÉREZ ${ }^{1}$, JULIO PÉREZ SERRANO ${ }^{2}$ \\ and JUAN C. MENDOZA SÁNCHEZ ${ }^{2}$ \\ ${ }^{1}$ Applied Physics Dpt., University of Cádiz. Polígono Río San Pedro s/n. Puerto Real, 11510, Cádiz, Spain. \\ E-mail: josejuan.alonso@uca.es \\ ${ }^{2}$ Contemporary History Dept., University of Cádiz. Bartolomé Llompart s/n, 11003, Cádiz, Spain
}

\begin{abstract}
SUMMARY: Tidal mills were the main industrial activity in the Bay of Cadiz for centuries. They were the last step in the production of salt and flour made by grinding grains. They were installed along the shallow channels, called "caños", around the Bay, where the frictional and geometrical effects are very strong. The authors have analyzed the propagation of the semidiurnal tidal waves along the Caño de Sancti Petri and the available tidal power in the area. The ancient tidal mills were located where the available tidal potential energy is highest, which ensured productivity for grinding salt and wheat in ancient times. Some considerations about the possibility of installing tidal power plants in the Bay of Cadiz now are given, which show that it could be a real and renewal alternative source of energy for the area.
\end{abstract}

Keywords: Ancient tidal mills, long shallow channels, tidal wave propagation

RESUMEN: EXPLOTACIÓN DE ENERGIA DE MAREAS EN LA BAHÍA DE CÁdIZ: MOLINOS DE MAREA históRICOS. Los molinos de marea fueron durante siglos la actividad industrial más importante de la Bahía de Cádiz. Eran, con la molienda, el último paso de la cadena de producción de la sal y los cereales. Estaban localizados en los canales largos y poco profundos de los alrededores de la Bahía de Cádiz, denominados "caños". En ellos los efectos de fricción y geométricos tienen gran importancia. Los autores analizan la propagación de las ondas de marea semidiurnas a lo largo del Caño de Sancti Petri y la potencia de marea disponible en él. La localización de los molinos de marea antiguos corresponde a los lugares donde la energía potencial de la marea es máxima, asegurando, en aquel entonces, una alta producción en la molienda de sal y cereal. Se considera la posibilidad de explotar la energía de mareas industrialmente en términos de centrales mareomotrices, siendo una alternativa real como fuente de energía alternativa para la zona.

Palabras clave: Molinos de marea históricos, canales largos y someros, propagación de la onda de marea.

\section{INTRODUCTION}

Tidal mills were the main industrial activity in the Bay of Cadiz during the 14th century up to the 19 th century. They were the last step in the production of salt and flour made by grinding grain. All salt and grain production was processed in the tidal mills of the area and it is well documented in the

*Received January 30, 2004. Accepted March 29, 2005. historical files of the local museums and civil authorities. Nowadays the buildings of the ancient tidal mills are abandoned and there are no successful plans for their restoration or for exploiting them in terms of tidal power plants, there is only some interest in them being used for bird watching. Some of them are well conserved thanks to private initiatives; however, they are not accessible to the public. Despite this, they are interesting from a scientific point of view and some questions arise when study- 
a)

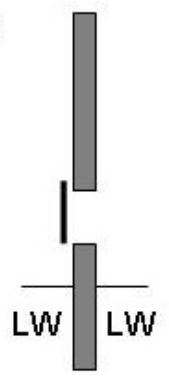

b)

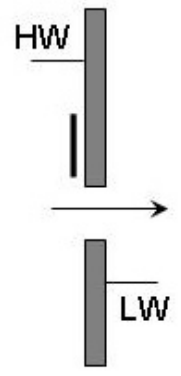

c)

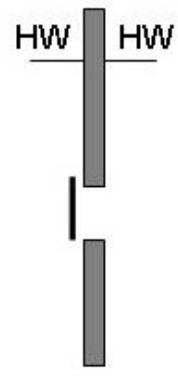

d)

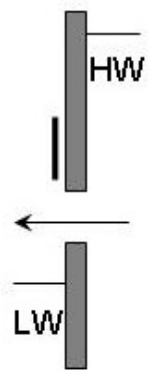

e)

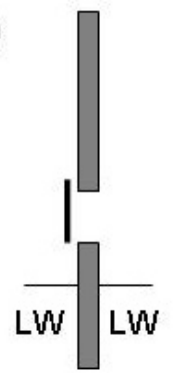

FIG. 1. - Scheme of the basic exploitation cycle of a tidal mill. It starts with the same water level (say low water (LW)) inside and outside the mill (horizontal thin line) and with the dam closed (a). The water level outside the mill goes to high water (HW), the dam is opened (solid vertical black line) and the water flows into the reservoir moving a mechanical device (b). When the water level is the same (HW) both inside and outside, the dam is closed (c). The level outside the mill goes to low water (LW), the dam is opened and the water flows out of the reservoir moving the mechanical device again (d). Then the water level is the same inside and outside the reservoir (LW), the dam is closed and the cycle starts again (e).

ing them. Why were their locations chosen in that particular way? How much tidal power was available? Is it possible to restore them to be used as tidal power plants? If so, how much energy could be extracted?

Since the structure of some ancient tidal mills still remains, it is possible to sketch some general characteristics. The main building could be perpendicular to the channel breaking the water flow. The channel was on one side and the mill's reservoir on the other. The other possible configuration was with the main building parallel to the channel with dams connecting the outer and inner part of the mill. The inner part of the mill had a reservoir connected to the channel by means of one or several holes with a dam at the end. The workers could always operate on the dam in order to make the maximum water level different in the inner and outer parts of the reservoir. When opening the dam, the water moved some buckets and their movement was transferred to circular stones used to grind the grains (Molina, 2001; Azurmendi, 1985). The basic scheme of exploitation is summarized in Figure 1. The number

of grinding stones depended on the available tidal power and on the permission given by the local authorities. The amount of tidal energy depended on the area of the reservoir and the location of the tidal mill. The area of the reservoir depended on the funds the owner invested but the location of the tidal mill depended on the tide. Even though this last factor was unknown for the people of such ancient times they chose the best places to locate the mills.

The study is focused on the Caño de Sancti Petri (CSP) located in San Fernando, close to Cadiz, at $36.5^{\circ} \mathrm{N}$ (Fig. 2). It is a doubly connected shallow water channel $17 \mathrm{~km}$ long. The mean depth is $9 \mathrm{~m}$ at the mouths and $3 \mathrm{~m}$ in the middle. The northern part is connected to the inner part of the Bay of Cadiz at La Carraca, and the southern part is connected to the Atlantic Ocean at Sancti Petri. It has many secondary channels that feed a very complex system of

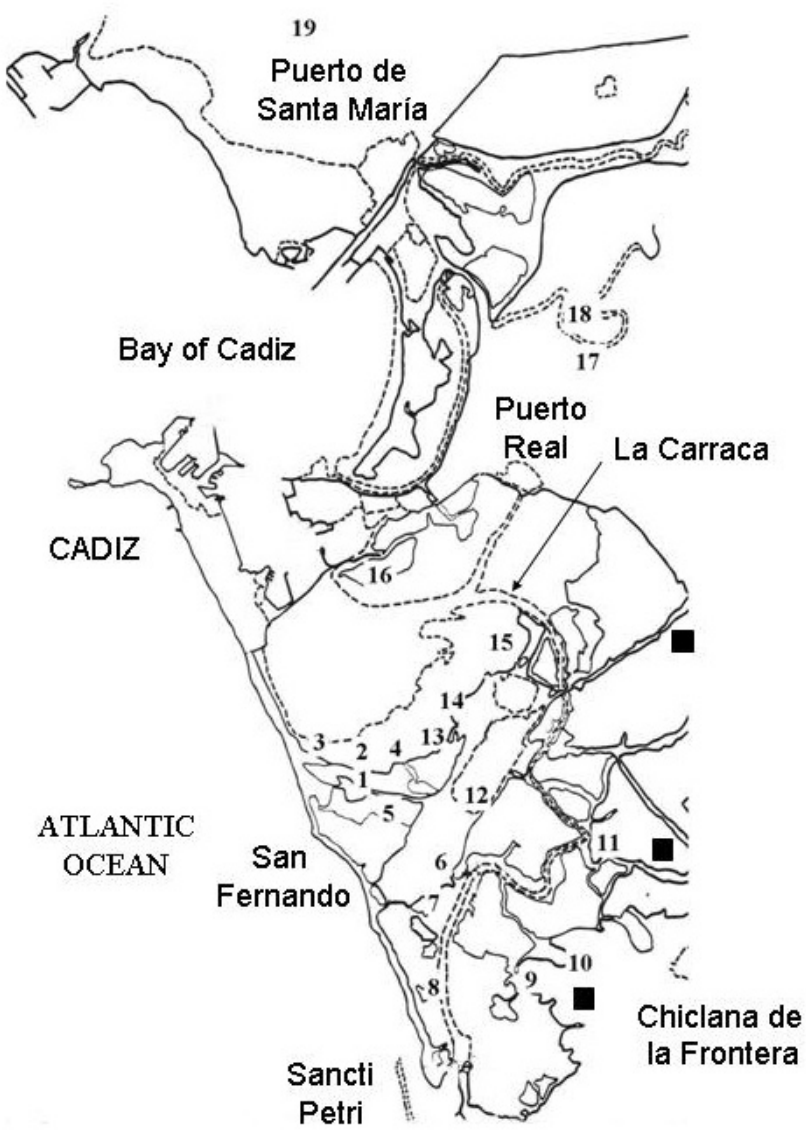

FIG. 2. - Area under study. The Caño de Sancti Petri feeds the secondary channels with a large area of marshes. The approximated locations of the ancient tidal mills in the Bay of Cadiz are: 1) Rio Arillo; 2) Santibañez; 3) Sierra; 4) San José; 5) de Soto; 6) Santa Cruz; 7) Montecorto; 8) Ormaza; 9) Bartivas; 10) La Aceña; 11) Ocio; 12) Zaporito; 13) Caño Herrera; 14) Fadricas; 15) El Pilar; 16) Trocadero; 17) Mendoza; 18) Goyena; 19) del Puerto. (After Molina 2001). The small solid squares denote the location of the main secondary channels, from South to North these are: Carboneros, Iro and Zurraque. 
small channels with large areas of marshes. These characteristics make a numerical modelling quite difficult (Vidal, 2002; Vidal et al., 2002).

The most important tidal mills in San Fernando were located along the CSP (AMSF 1778). There were two conditioning factors for choosing their locations. The first one was that they must be far enough away from military installations (such as that located at La Carraca (Fig. 2)) and close enough to the towns in order to make transport and access as cheap and fast as possible. The authors will show that there were many places along one of the channels of the Bay of Cadiz where it was impossible to place a tidal mill. However, as it has been pointed out, the observed locations of the ancient tidal mills were the best possible locations.

\section{TIDAL MILLS IN SAN FERNANDO}

According to Molina (2001), the first reference to tidal mills was made by Al-Maqdisî referring to the mills existing in Basra (Iraq) in the 10th century. In Europe the oldest tidal mill was located in Dover in 1066. In the 12th century there were several tidal mills in France: Bayona (in 1120), Labourd (in 1125), Guérande (in 1182 owned by the Temple), Pencastel (in 1186) and Nantes (circa 1190). In the same century there were three in England: WoottonWight (in 1132), Bronley-by-Bow (in 1135) and Woodbridge (in 1170). In the same epoch there were six tidal mills in Spain located at Escalante, Avilés, Berengo, San Sebastián, Gazteluondo and Puerto Real (Trocadero, see Fig. 2). All of them were used to grind the cereal grain production of their surrounding areas. They were all located in places where the tidal range was higher than $2 \mathrm{~m}$.

During the 14th up to the 19th century, bread was the staple diet of the population of the Bay of Cadiz. Grain production and its post-processing into flour were one of the most important economical and industrial activities. The grinding methods evolved, becoming more sophisticated and economical and tidal power was preferred to animal or wind power. It was not until the 15 th century that tidal mills were built in the Bay of Cadiz. There are 20 reported tidal mills: 3 in Cadiz, 5 in San Fernando, 5 in Chiclana, 6 in Puerto Real and 1 in the Puerto de Santa María. Among these the authors have focused on those located in San Fernando along the CSP. The locations of the known and most important tidal mills in the Bay of Cadiz are presented in Figure 2. As there are several names for the same mill, we have used the most popular names.

Among the five tidal mills located in San Fernando, there were three that performed most of the grinding: San José, Zaporito and Caño Herrera (Fig. 2). However, they were not isolated because they were part of a grain grinding network in Cadiz, San Fernando and Chiclana. The ancient tidal mill of San José is the oldest, as it was built before 1625 but the exact date is unknown. It started with four grinding stones and at the end of the 18th century it had eight stones (AHPC 5581). The ancient tidal mill of Zaporito, also known as Ureña, was built in 1756. It had 24 grinding stones (AHPC 5578). Finally, the ancient tidal mill of Caño Herrera was built in the 18 th century before 1752 , the exact date is unknown. It had four grinding stones (AMSF 1752; AMSF 1752). The total amount of grain ground (i.e. the flour obtained) by the three mills was more than $8650 \mathrm{~kg}$ per day during centuries (AMSF 1778). This is a very good indicator of the importance of the tidal mills in the area.

Tidal mills in San Fernando and its surroundings stopped their activity because the industrial revolution introduced steam as an alternative power source (Acosta, 1995). Some of them were reconverted into sawmill that still using tidal power. There were two main reasons for abandoning grinding activity using tidal mills in the Bay of Cadiz. The first was due to the shallow channels not being maintained by periodical dredging due to the Cuban War and the second was the railway. The local navy authority was responsible for maintenance and the influence of the railway was a result of the bakeries buying lower quality, cheaper flour from other places (Anes, 1998).

\section{NUMERICAL MODEL AND TIDAL POWER}

\section{Numerical model}

The study of tidal wave propagation in two sided open channels is a particular case of tidal wave propagation in channels (Petrie, 1999; Harari and Cartago, 2003; Henderson, 1966; Prandle, 1985). These channels have their own characteristics due to the hydrodynamic of the water masses on both sides. This is the case of the CSP. According to Vidal et al. (2002) and Vidal (2002), the CSP is a non-stratified estuarine system and the vertical component of the velocity is, at least, one order of magnitude less than any of the transversal velocity components. Hence, 
Table 1. - Time lags for the M2 tidal wave from Sancti Petri (distance from Sancti Petri and lags in minutes).

\begin{tabular}{lr}
\hline Station & Lag \\
\hline Gallineras $(4.9 \mathrm{~km})$ & +8.96 \\
Estación Río Iro $(9.0 \mathrm{~km})$ & +15.71 \\
Zurraque $(9.8 \mathrm{~km})$ & +15.85 \\
Zaporito $(11.25 \mathrm{~km})$ & +8.88 \\
La Carraca $(15.45 \mathrm{~km})$ & +3.91 \\
\hline
\end{tabular}

a one-dimensional approach is suitable for studying the problem. In addition, the incoming tidal waves have a small difference in the phase lag (Vidal, 2002; Vidal et al., 2002). The time difference for the M2 tidal wave with respect to the Sancti Petri station is presented in Table 1. The numerical model has been developed including the main secondary channels of the area, Zurraque, Carbonero and Rio Iro (Fig. 2). The study of the tidal wave propagation along the CSP has been carried out following the algorithm developed by Cunge (1975).

The numerical solution is based on the method of finite differences and it uses the Abbot-Ionescu scheme with branched channel solution algorithms (Abbot, 1979; Lanzoni and Seminara, 1998). The upstream open boundary of the channel was located at La Carraca and the downstream boundary was at Sancti Petri (Fig. 2). The boundary conditions at the open ends were the M2, S2, N2, O1 and K1 tidal constituents obtained from the harmonic analysis of real data sets. The model was validated by deploying RCM7 currentmeters at Sancti Petri and Gallineras, and WLR7 water level recorders at Sancti Petri, Gallineras, Iro and Zaporito for more than one month.

The Verwey variation has been taken into account when applying the Abbot-Ionescu discretization scheme (Abbot, 1979; Lanzoni and
Seminara, 1998). This computes the sea surface elevation and caudal at times $t$ and $t+1$ and the areas, widths and wet perimeters in time $t+1 / 2$. The final scheme is conservative, fast and numerically stable.

Considering a constant density, the 1D dynamic can be described in terms of the sea surface, $x$, and the caudal through a transversal section, $Q$. These are functions of the along channel coordinate, $x$, and time, $t$. The velocity field and the depth can be computed from the relationships:

$$
\begin{gathered}
u=Q / A \\
H=x+H_{m}
\end{gathered}
$$

where $A$ is the area of the section $Q$ and $H_{m}$ is the average depth of the computation cell.

The equations for the mass and momentum conservations are:

$$
\begin{gathered}
\frac{\partial \xi}{\partial t}+\frac{1}{b} \frac{\partial Q}{\partial x}=0 \\
\frac{\partial Q}{\partial t}+\frac{\partial}{\partial x}\left(\frac{Q^{2}}{A}\right)+g A \frac{\partial \xi}{\partial x}+C d \frac{Q|Q| P}{A^{2}}=0
\end{gathered}
$$

where $b=b(x, t)$ and $A=A(x, t)$ are the width and the area of a transversal section respectively. $P=P(x, t)$ is the wet perimeter of a given section at time $t$ and $C d$ is the bottom friction coefficient.

The initial conditions correspond to a cold start

$$
\begin{aligned}
& Q(x, 0)=0, \forall x \neq 0, L \\
& \xi(x, 0)=0, \forall x \neq 0, L
\end{aligned}
$$

\begin{tabular}{|c|c|c|c|c|c|c|c|c|c|c|}
\hline \multirow{2}{*}{$\begin{array}{l}\text { Wave } \\
\text { Station }\end{array}$} & \multicolumn{2}{|c|}{ M2 } & \multicolumn{2}{|c|}{ S2 } & \multicolumn{2}{|c|}{$\mathrm{N} 2$} & \multicolumn{2}{|c|}{$\mathrm{O} 1$} & \multicolumn{2}{|c|}{ K1 } \\
\hline & $\mathrm{O}$ & M & $\mathrm{O}$ & M & $\mathrm{O}$ & M & $\mathrm{O}$ & M & $\mathrm{O}$ & M \\
\hline Sancti Petri & $\begin{array}{l}96 \\
58\end{array}$ & 97 & 30 & 32 & 20 & 24 & 6 & 5 & 6 & 6 \\
\hline Gallineras & $\begin{array}{l}99 \\
61\end{array}$ & $\begin{array}{l}99 \\
61\end{array}$ & $\begin{array}{l}32 \\
89\end{array}$ & $\begin{array}{l}33 \\
89\end{array}$ & $\begin{array}{l}24 \\
43\end{array}$ & $\begin{array}{l}24 \\
42\end{array}$ & $\begin{array}{c}5 \\
292\end{array}$ & $\begin{array}{c}5 \\
289\end{array}$ & $\begin{array}{c}6 \\
42\end{array}$ & $\begin{array}{c}6 \\
38\end{array}$ \\
\hline Iro & $\begin{array}{l}98 \\
67\end{array}$ & $\begin{array}{c}100 \\
64\end{array}$ & $\begin{array}{l}35 \\
98\end{array}$ & $\begin{array}{l}34 \\
93\end{array}$ & $\begin{array}{l}21 \\
49\end{array}$ & $\begin{array}{l}24 \\
45\end{array}$ & $\begin{array}{c}6 \\
301\end{array}$ & $\begin{array}{c}6 \\
296\end{array}$ & $\begin{array}{r}5 \\
52\end{array}$ & $\begin{array}{c}6 \\
49\end{array}$ \\
\hline Zaporito & $\begin{array}{c}101 \\
70\end{array}$ & $\begin{array}{c}102 \\
68\end{array}$ & $\begin{array}{l}34 \\
99\end{array}$ & $\begin{array}{l}34 \\
98\end{array}$ & $\begin{array}{l}23 \\
50\end{array}$ & $\begin{array}{l}24 \\
47\end{array}$ & $\begin{array}{c}6 \\
303\end{array}$ & $\begin{array}{c}6 \\
302\end{array}$ & $\begin{array}{c}7 \\
53\end{array}$ & $\begin{array}{c}7 \\
51\end{array}$ \\
\hline
\end{tabular}

The boundary conditions are the sum of the tidal harmonics M2, S2 and N2 at both ends of the channel obtained from the harmonic tidal predictions.

TABLE 2. - Comparison of the results of the numerical model (M) with experimental data for tidal elevations along the CSP (O). The upper numbers are the amplitudes $(\mathrm{cm})$ and the lower numbers the phase lags (degrees) at the moorings. 
TABLE 3. - Same legend as Table 2 but for the currents at the M2 frequency. Amplitudes are in $\mathrm{cm} \cdot \mathrm{s}^{-1}$ and phase lags in degrees. The Puente de Hierro station is very close to La Carraca.

\begin{tabular}{lcccc}
\hline & \multicolumn{2}{c}{ Observed } & \multicolumn{2}{c}{$\begin{array}{c}\text { Model } \\
\text { Phase lag }\end{array}$} \\
& A & Phase lag & A & \\
\hline Sancti Petri & 23 & 331 & 25 & 331 \\
Puente Hierro & 16 & 181 & 20 & 183 \\
\hline
\end{tabular}

The time step was $5 \mathrm{~s}$ and the spatial cell was $75 \mathrm{~m}$ long in order to satisfy the CFL criterion. The origin of distances was taken in Sancti Petri, increasing northward. The simulation time was 30 days in order to obtain a long enough time series for the harmonic analysis of the output. After some trials and errors, the chosen value of the bottom friction coefficient was $C d=0.003$ because it was the value that best fitted the experimental data. The comparison of the model's results using several $C d$ with the values from the analysis of the real data is presented in Figure 3 for the case of the M2 tidal wave. It is clear that the selected value of $C d$ gives estimations that are closer to the results from the experimental data.

The good fit of the results of the numerical model assuming the $C d=0.003$ can be observed from the results in Table 2 for tidal elevations. Semidiurnal and even the small diurnal tidal waves are very well fitted. The fit for the M2 tidal current is also very good (Table 3).

Other parameters of interest that can be computed from the output of the model are the flux and dissipation of energy. From the equations of motion (Eq 1 and 2) it is possible to obtain that the energy of the unit element of area is:

$$
E=\frac{1}{2} \rho\left[H u^{2}+g \xi^{2}\right]
$$

where the first term is the potential and the second one is the kinetic energy. From Equation (5) and with the equations of motion, it is straightforward to get the energy balance equation for shallow waters:

$$
\frac{\partial E}{\partial t}+\nabla \cdot\left[\frac{1}{2} \rho H\left(u^{2}+2 g \xi\right) \cdot \vec{u}\right]=\rho\left[-r|\vec{u}|^{3}\right]
$$

where is the divergence operator, the mean velocity $(u=Q / A)$ and its modulus. This expression shows that the temporal variation of energy per unit of area is due to the divergence of the flow and to the dissipative effect of friction, which leads to studying the contribution of each tidal wave considered.

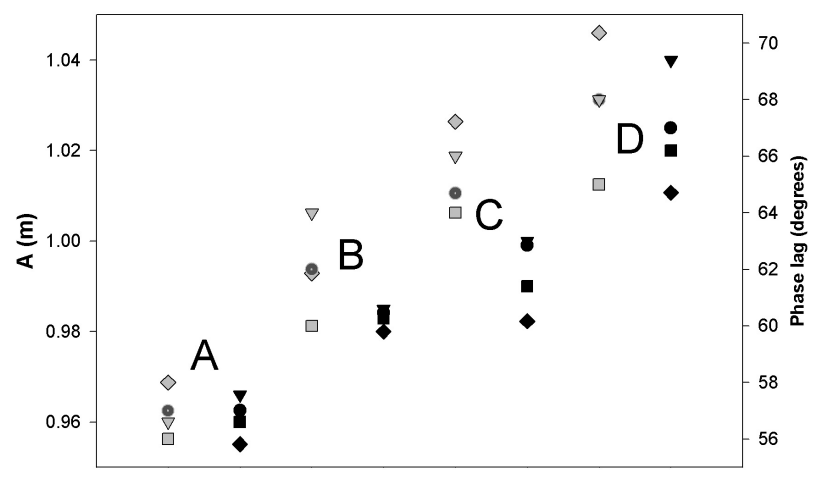

FIG. 3. - Amplitudes (black) and phase lags (grey) of the M2 tidal wave elevations from the numerical model at the stations of Sancti Petri (A), Gallineras (B), Iro (C) and Zaporito (D) for $C d=0.002$ (square), $C d=0.003$ (circle), $C d=0.004$ (upside down triangle). Results for the observed data sets are presented with diamonds.

When the average is performed in a tidal cycle, the difference of energy between the incoming and outgoing tide must be balanced with its dissipation, which is a direct computation. The energy flux is computed from the spatial derivative of Equation (5) along the channel.

\section{Tidal power}

Two kinds of energy can be extracted from the mechanical phenomenon of tides: kinetic and potential. Both can be transformed into the motion of grinding stones or to electric energy for industrial exploitation by means of mechanical devices. Kinetic energy can be extracted using tidal turbines and potential energy by creating a difference between the levels of the outer and inner parts of an associated installation such as a reservoir (Fig. 1). According to Godin $(1969,1988)$, kinetic energy is extracted by the sides and potential energy by the vertical; the last method is more efficient.

The ancient tidal mills could extract the potential energy by means of a reservoir that was filled up by the tide by means of small dams in order to create the largest possible difference of potential energy (level) between the outer and inner parts of the dams. The potential energy was transformed into the movement of grinding stones to grind salt and grain.

Tidal power is computed from the well-known equations of hydrodynamics:

$$
\begin{gathered}
\frac{d \vec{v}}{d t}=\vec{g}-\frac{1}{\rho} \vec{\nabla} p-2 \vec{\Omega} \times \vec{v}+\vec{T}+\vec{F} \\
\vec{\nabla} \vec{v}=0
\end{gathered}
$$


where $\vec{v}$ is the velocity vector $\vec{v}=\{u, v, w\}, \overrightarrow{\mathrm{g}}=$ $\{0,0, g\}$ the gravity vector, $p$ is the pressure, $\rho$ the water density, $\vec{\Omega}$ is the Earth's rotation vector, $\vec{T}$ is the tidal force and $\vec{F}$ is the friction term. After some simple algebra and additional considerations about the tidal energy, Equations 7 and 8 lead to some simple results used for computing the tidal power. These are very well summarized in the remarkable, indepth paper by Godin (1969), and a comprehensive selected summary can be found in Godin (1988). The result, when friction is not considered, is the socalled power transfer vector defined as:

$$
\vec{P}=\rho g H \eta \vec{v}
$$

where $H$ is the depth and $\eta$ is the tidal elevation of the free surface. Since the tide is harmonic, the elevation and velocity can be expressed as:

$$
\begin{gathered}
\eta=\eta_{0} \cos (\omega t) \\
\vec{v}=[M \cdot \cos (\omega t-\varphi), m \cdot \sin (\omega t-\varphi)]
\end{gathered}
$$

where $\eta_{0}$ is the amplitude of the tidal elevation, $M$ and $m$ are the mayor and minor semi-axes of the current ellipse of the tidal component of frequency $\omega, t$ is the time and $\varphi$ is the phase of the current. Substituting Equations 10a and 10b in 9, the power transfer vector is:

$$
\begin{gathered}
\frac{\vec{P}}{\rho}=g H \eta \vec{v}=g H \eta_{0} \cos (\omega t) . \\
{[M \cdot \cos (\omega t-\varphi), m \cdot \sin (\omega t-\varphi)]=} \\
=\frac{1}{2} g H \eta_{0}\{[M \cdot \cos (\varphi), m \cdot \sin (\varphi)](1+\cos (2 \omega t))+ \\
+[M \cdot \sin (\varphi), m \cdot \cos (\varphi)] \sin (2 \omega t)\}
\end{gathered}
$$

The two components of the power transfer vector are called the pulsating, $P_{p}$, and alternating vector, $P_{a}$, defined as:

$$
\begin{gathered}
P_{p}=\frac{1}{2} g H \eta_{0} \times \\
\times\{[M \cdot \cos (\varphi), m \cdot \sin (\varphi)](1+\cos (2 \omega t))\} \\
P_{a}=\frac{1}{2} g H \eta_{0}\{[M \cdot \sin (\varphi), m \cdot \cos (\varphi)] \sin (2 \omega t)
\end{gathered}
$$

The average of Equations 12a and 12b in a tidal cycle are:

$$
\begin{gathered}
\bar{P}_{p}=\frac{1}{2} g H \eta_{0}\{[M \cdot \cos (\varphi), m \cdot \sin (\varphi)]\} \\
P_{a}=0
\end{gathered}
$$

If the harmonic constants of the tide and the currents are known, together with the mean depth and width of the area $(d y)$, then the averaged pulsating power transfer is:

$$
\overline{P_{p}}=\frac{1}{2} g H \eta_{0}\{[M \cdot \cos (\varphi), m \cdot \sin (\varphi)]\} d y
$$

which gives the maximum power that can be extracted from the tide without friction.

When friction is considered it is well-known that the elevation and current will present an additional phase lag. Hence Equation 14 is slightly modified to:

$$
\begin{gathered}
\overline{P_{p}}=\frac{1}{2} g H \eta_{0} \times \\
\times\{[M \cdot \cos (\psi-\varphi), m \cdot \sin (\psi-\varphi)]\} d y
\end{gathered}
$$

where $\psi$ is the phase of the tidal elevation. From Equation 15 it is clear that the averaged tidal power depends strongly on the difference of the phases between elevation and currents.

\section{RESULTS AND DISCUSSION}

\section{Numerical model}

The results for the sea surface elevation are similar for the three semidiurnal tidal waves considered. Amplitudes rise from south to north and the phase lags present a maximum close to the Isla Vicario (Fig. 4). The M2 tidal wave has $97 \mathrm{~cm}$ in Sancti Petri and $107 \mathrm{~cm}$ in La Carraca. There is a sudden increase in the amplitude and a fall in the phase lag close to Zaporito. The time lags of the M2 tidal wave with respect to Sancti Petri are shown in Table 1. The increment in the phase lag along the channel can be computed as the time lag by means of $\Delta t=\Delta \varphi / \omega$; where $\Delta t$ is the lag, $\Delta \varphi$ is the relative difference of the phase lag and $w$ is the tidal wave frequency. The maximum value is about 16 minutes close to Caño Zurraque. The reason for this is due to the two incoming (northward and southward) tidal waves meeting at Zaporito with a close phase lag. The S2 and N2 tidal waves are similar with lower ampli- 

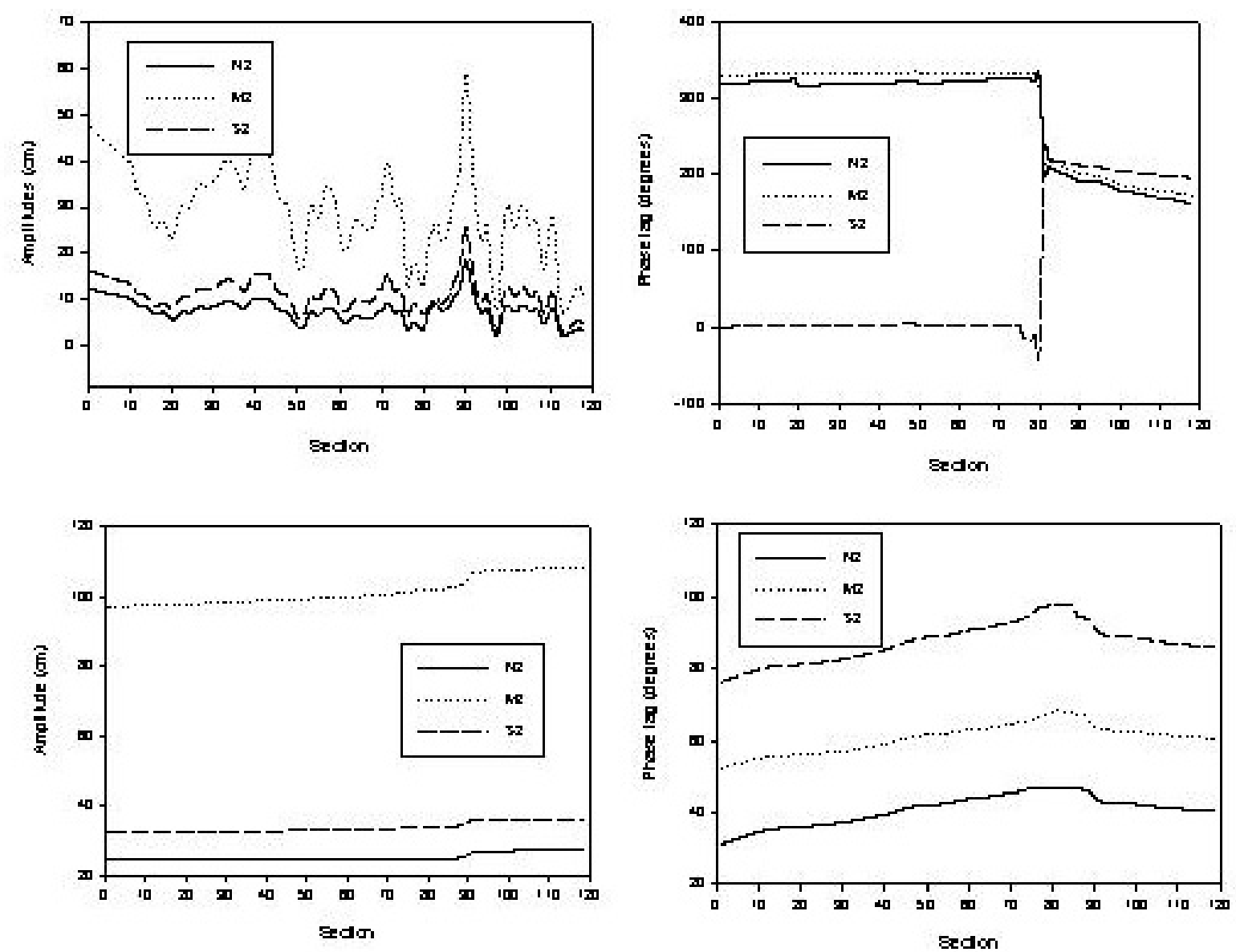

FIG. 4. - Amplitudes and phase lags of the M2, S2 and N2 tidal waves. Upper left for the amplitudes of tidal elevation, upper right for the phase lags. Bottom left and right is the same for currents. Sections denote the number of $75 \mathrm{~m}$ long sections used in the numerical model from Sancti Petri.

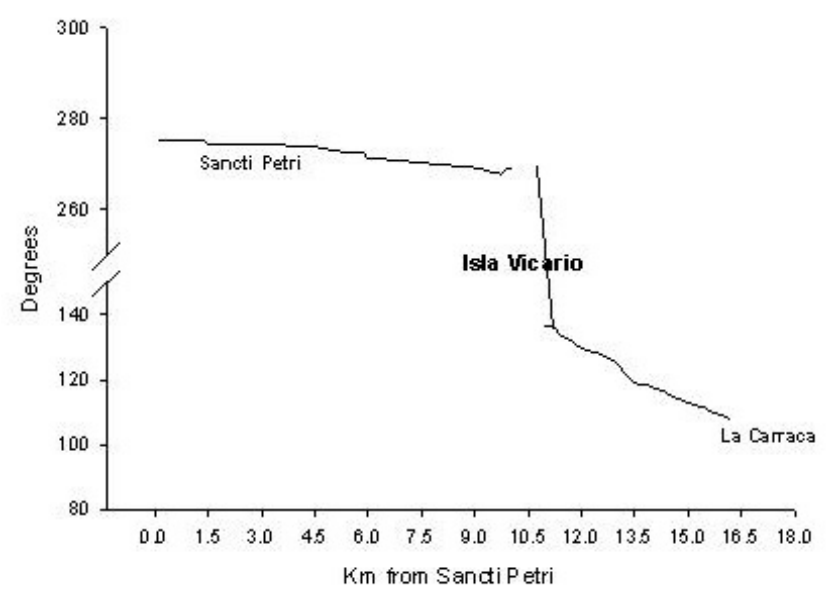

FIG. 5. - Difference of phase lag between elevations and velocities for the M2 tidal wave along the CSP.

tudes (Fig. 4). Due to this, the study will be focused on the M2 tidal wave.

The evolution of the difference of the phase lag between elevations and currents for the M2 tidal wave along the CSP is presented in Figure 5. It seems to be a stationary wave at both sides of the channel and to have a more quasi-stationary oscilla-

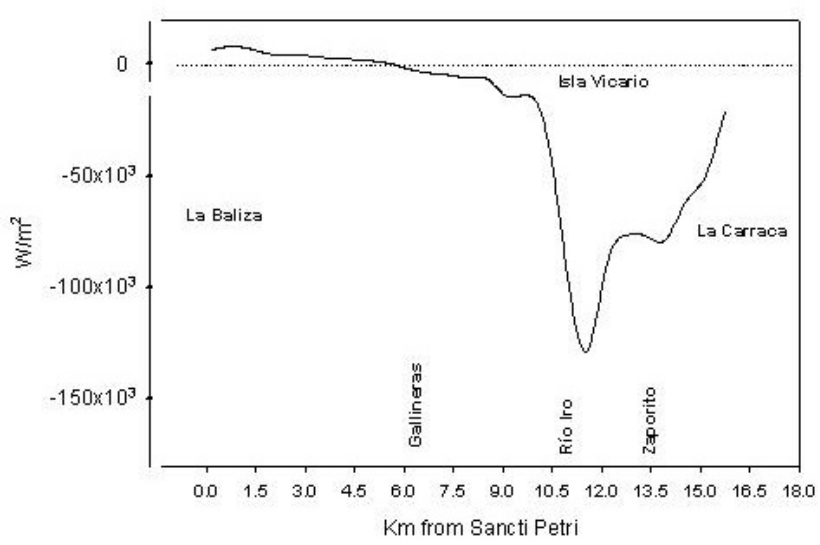

FIG. 6. - Energy flux $\left(\mathrm{W} / \mathrm{m}^{2}\right)$ for M2 along the channel. The sign indicates the direction, positive represents northward (from Atlantic Ocean to the inner Bay).

tion southward. Close to Gallineras the difference is $270^{\circ}$. This will be very important when evaluating the available tidal power.

The energy balance was computed by means of Equation (6) considering the divergence of the mean flow and the power dissipation along the channel for the M2 tidal wave (Fig. 6). Hence, where there are 


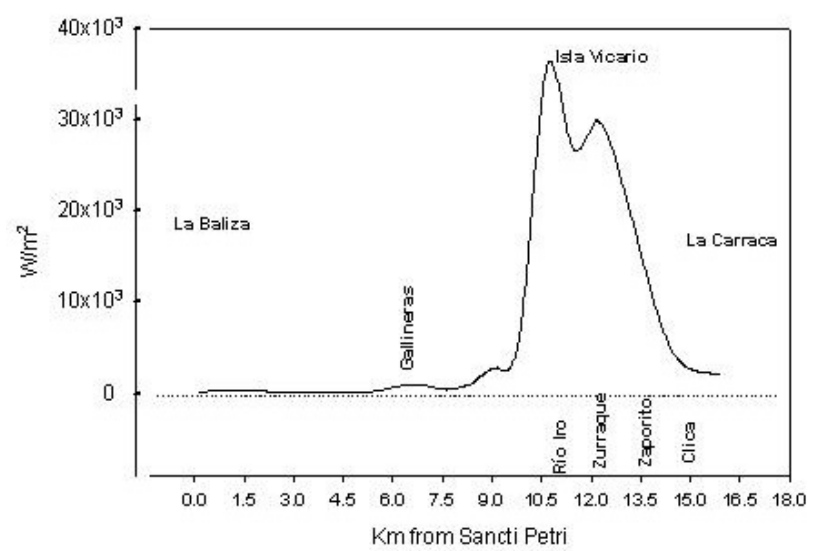

FIG. 7. - Energy dissipation (W/m $\left.{ }^{2}\right)$ for M2 along the CSP.

greater mean flow variations, there will be greater dissipation due to frictional effects. The energy flux is mainly directed southward.

The tidal energy dissipation is presented in Figure 7. It is very low from Gallineras to La Carraca with a maximum close to Rio Iro. It is especially interesting that the energy dissipation distribution presents a local minimum at Zaporito. These features are important when choosing the location of a tidal mill, as it will be seen further on.

\section{Tidal power}

From the results of the numerical model, the harmonic constants of the elevation and currents can be found for each section considered. In addition, the mesh of computation provides their depth and width. The results of the computation of the tidal power using Equations 14 and 15 are presented in Figure 8. The upper one is for the $\mathrm{N} 2$ tidal wave, the middle one for M2 and the lower one for S2. The solid line is for the tidal power without friction and the dashed line is when the friction is taken into account. In the absence of friction, for the M2 wave, the tidal power reaches $12 \mathrm{GW}$ per tidal cycle at the mouth of the channel (Sancti Petri). For N2 and S2 the tidal power is $1.2 \mathrm{GW}$ and $0.5 \mathrm{GW}$ respectively. Tidal power is not available for all the tidal waves in Gallineras (Section 77). This is a direct consequence of the difference of the phase lag between elevation and current as pointed out previously.

In long shallow channels the frictional effects are very important and the main effect, despite the changes in the amplitudes of the propagating tidal waves, is the change in the difference between the phase lags of the elevations and currents. When friction is taken into account, the available tidal power
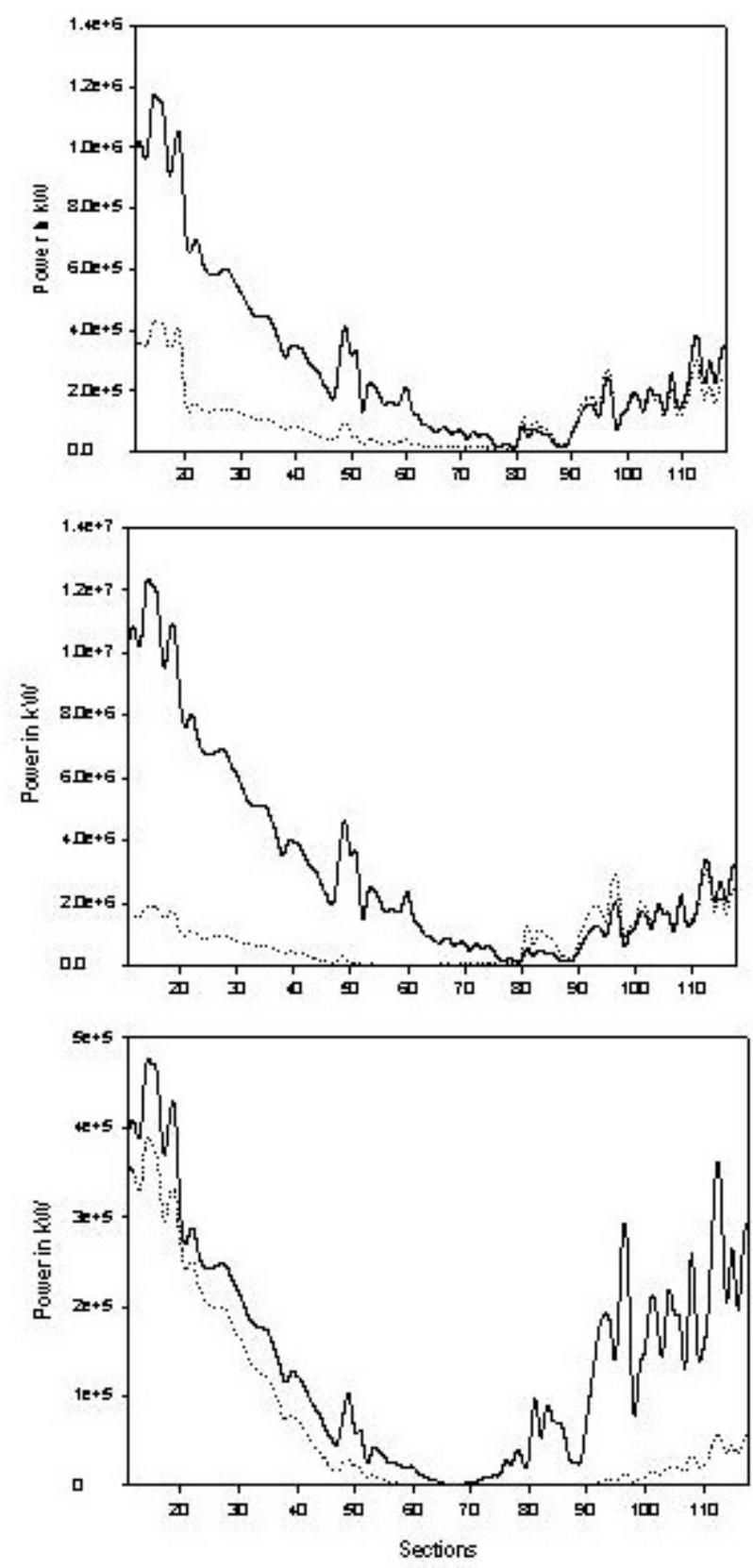

FIG. 8. - Available tidal power along the CSP for N2 (upper panel), M2 (mid panel) and S2 (bottom panel). Dashed lines are when friction is considered and solid lines without friction.

falls drastically and has a maximum of $3 \mathrm{GW}$ in Zaporito, where the most important tidal mill in the CSP was located (Section 90). The results, both when considering and not considering the frictional effects point to Zaporito as the best location for a tidal mill.

It is worth noting that the $\mathrm{N} 2$ and M2 waves feel the frictional effects from the beginning of the channel while S2 is quite insensitive to them. Hence, for the $\mathrm{S} 2$ wave the available tidal energy is equal to the tidal energy in the case of friction. In the middle of 
the channel, and due to the geometry, the phase lags of elevations and currents play an important role in reducing the available tidal power for all the waves, therefore making it the poorest locations for tidal mills. Nevertheless the maximum tidal power corresponds to the M2 wave that reaches about $13 \mathrm{MW}$ per tidal cycle close to the Sancti Petri port.

Figure 8 also gives an idea about where a tidal mill would have the highest productivity. From the results it is clear that the best locations were from Sancti Petri to Gallineras and Zaporito where the most tidal power is available. This is supported by the historical evidence of the number of grinding stones inside the ancient tidal mill of Zaporito (see above).

The efficiency of extracting energy is constrained by the volume of the associated reservoirs of each tidal mill and by the kind of installations in them. In addition, the neap tides have not been taken into account. From the historical references it is known that when there were neap tides the mill stopped its grinding activity for two or three days. This operational practice is also applied nowadays in the existing modern tidal power plants (Godin, 1969). The estimations of tidal power from Figure 8 are valid only for the current bathymetry; it is necessary to recover the ancient one in order to get more realistic results for the epoch. Unfortunately these data do not exist in the historical data files.

\section{FURTHER CONSIDERATIONS}

The industrial exploitation of tidal power in the Bay of Cadiz by means of tidal power plants has not yet been considered. In order to do so it is necessary to adapt an old structure or build a new one. Hence, the environmental impact will be extremely low or inexistent because this activity has been carried out from ancient times. The ancient structures have a reservoir with a volume capacity much greater than an Olympic pool (say $50 \times 30 \times 2 \mathrm{~m}^{3}$ ) and also a much greater area $\left(50 \times 30 \mathrm{~m}^{2}\right)$. If the area of the reservoir is taken into account, the potential extracted energy due to the difference of the water level in the tidal cycle is (Godin, 1969, 1988):

$$
E=E_{1}-E_{2}=2 \rho g \int_{0}^{2 \eta_{0}} z S(z) d z \approx \rho g S_{0}^{2}\left(2 \eta_{0}\right)
$$

where $S_{0}$ is the area of the reservoir and the meaning of the other symbols is known. Considering the val- ues of $\eta_{0}=2 \mathrm{~m}, S_{0}=50 \times 30 \mathrm{~m}^{2}, g=9.81 \mathrm{~m} \mathrm{~s}^{-2}$ and $\rho$ $=1025 \mathrm{~kg} \mathrm{~m}^{-3}$, the upper limit of available energy is about $90 \mathrm{MW}$ per tidal cycle and $180 \mathrm{MW}$ per day. The greater the area of the reservoir the more energy is available.

Hence, if an old tidal mill structure is available for restoration, taking into account some modifications due to current engineering techniques, and heavy duty double sense operated turbines are deployed with an automatic control system, it could be possible to extract at least half of the available energy computed above, making it possible to introduce a clean, renewable and predictable energy source into the Bay of Cádiz.

It would be possible to install a tidal power plant in the Bay of Cadiz, just in the heart of the Natural Park of the Bay of Cadiz, due to the very low environmental impact of the tidal power plant, by using or adapting the existing reservoirs and ancient buildings.

\section{CONCLUSIONS}

The authors have analyzed the propagation of the main semidiurnal tidal waves along the CSP in order to perform some computations of the available tidal power along it. It has been shown that M2 and N2 feel the frictional effects more severely than S2 and that the tidal power is highly dissipated along the channel with a southward energy flux. The power transfer vector has been computed along the CSP from the results of the numerical model. There were many locations where a tidal mill could be located but some constraints such as the proximity of a naval base or the distance from towns made these locations impossible. From the results of the numerical model, the best possible location for an ancient tidal mill in the CSP was Zaporito. In addition, it is inside the town of San Fernando. The historical files of museums show that the tidal mill located there had 24 grinding stones.

There is one remaining question that can now be answered. How was it possible in ancient times to determine the best place for the location of a tidal mill? From the results the answer is now simple. The tidal power is a function of the available potential energy for a given location using dams and reservoirs. Hence, the best places were determined by simple measurements of the difference in the water level between high and low water in spring tides. According to these measurements the best 
location corresponds to Zaporito, where the most important ancient tidal mill in the CSP was located. There are two more suitable locations: La Carraca and Sancti Petri. The first one was not possible due to its proximity to a naval base and the second was not useful because it was too far from the towns, making production more expensive due to transport costs. However, it can be noted that it is possible to place a tidal mill anywhere from Zaporito to $\mathrm{La}$ Carraca.

\section{ACKNOWLEDGEMENTS}

The authors are grateful to D. Julio Molina Font for some really interesting references about ancient tidal mills in the Bay of Cadiz and to the City Hall of Cadiz for sponsoring a cycle of conferences in the $\mathrm{LV}^{\text {th }}$ Summer Courses of the University of Cádiz. This work has been partially supported by the OT118/2000 contract.

\section{REFERENCES}

Abbot M.B. - 1979. Computational Hydraulics. Elements of the theory of free surface flows. Pitman.

Acosta, R. - 1995. Estudio de los molinos de marea en la Bahía de Cádiz. Campaña juvenil de protección del patrimonio arqueológico 1993-1994. Sevilla.

Anes, R. - 1998. Relaciones entre el ferrocarril y la economía española (1865-1935). In: Los ferrocarriles en España, 1844 1943, Vol I.

Archivo Histórico de Patrimonio Cultural, Protocolo 5578. Museo de Cádiz.

Archivo Histórico de Patrimonio Cultural, Protocolo 5581. Museo de Cádiz.

Archivo Municipal de San Fernando, 1752. Catrastro del Marqués de la Ensenada.

Archivo Municipal de San Fernando, 1752. Legajo 1940, Expediente 3.

Archivo Municipal de San Fernando, 1778. Legajo 1810, Expediente 2

Azurmendi, L. - 1985. Molinos de mar. Colegio Oficial de Arquitectos de Cantabria.

Cunge, J.A. - 1975. Applied mathematical modelling of the open channel flow. No. 10. Unsteady Flow in open Channels, Water Resources Publications. Colorado.

Godin, G. - 1969. Theory and Exploitation of Tidal Energy and Its Application to the Bay of Fundy. J. Fish. Res. Board Canada. 26, 11: 2887-2956.

Godin, G. - 1988. Tides. CICESE. Pp 290.

Harari J. and R. de Cartago. - 2003. Numerical simulation of the tidal propagation in the coastal region of Santos (Brazil, $24^{\circ} \mathrm{S}$ $\left.46^{\circ} \mathrm{W}\right)$. Cont. Shelf Res., 23: 1597-1613.

Henderson, F.M. - 1966. Open Channel flow. Macmillan, New York, 96-101.

Lanzoni S. and G. Seminara. - 1998. On tide propagation in convergent estuaries, J. Geophys. Res., 103, C13: 30793-30812.

Molina, J. - 2001. Molinos de marea de la Bahía de Cádiz (siglos XVI-XIX). Consejería de Medio Ambiente, Junta de Andalucía.

Petrie, B. - 1999. Sea level Variability in the Bras d'Or Lakes. Atmosphere-Ocean, 37: 221-239.

Prandle D. - 1985. Classification of tidal response in estuaries from channel geometry. Geophys. J.R. astr. Soc., 80: 209-221.

Vidal J. - 2002. Caracterización dinámica de la marea y del sedimento en el caño de Sancti Petri. Ph.D. thesis, Universidad de Cádiz, Departamento de Física Aplicada.

Vidal J., O. Alvarez, B. Tejedor and L. Tejedor. - 2002. Estudio de la señal $\mathrm{M}_{2}$ de la marea en el Caño de Sancti Petri. III Asamblea Hispano-Portuguesa de Geodesia y Geofísica. 4-8 febrero, Valencia.

Scient. ed.: A. Sánchez-Arcilla 